\title{
DAMPAK PENGEMBANGAN PEMASARAN DIGITAL PADA STARTUP'S (STUDI KASUS PADA WIRAUSAHA BARU)
}

\author{
Sri Aliami \\ Ema Nurzainul Hakimah \\ Diah Ayu Septi Fauji \\ Universitas Nusantara PGRI Kediri \\ srialiami@unpkediri.ac.id \\ emahakimah@unpkediri.ac.id \\ septifauji@unpkediri.ac.id
}

\begin{abstract}
This study aims to reveal the impact of digital marketing management on start - up. The study is a case study in an effort to show how the actual impact of digital marketing on start-ups. This research is a qualitative research with etnometodology approach. The study was conducted by direct observation and in-depth interviews on the new entrepreneurial community that became the vendor in the start-up of e-commerce at the Faculty of Economics, University of Nusantara PGRI Kediri. Informants selected with criterion $5 \mathrm{R}$. Observation itself is done when the transaction use of digital marketing application which then conducted an open interview to reveal the impact of management of digital marketing. The results of these observations and in-depth interviews in this study indicate that the management impact of digital marketing on start-up does increase start-up revenue but because the lack of ability to provide content and respond quickly to content that has been provided makes new entrepreneurs (startup) have not gained the most from the management of digital marketing.
\end{abstract}

Keywords: Digital Marketing, Start - up, e - commerce

\begin{abstract}
Abstrak
Penelitian ini bertujuan untuk mengungkap dampak pengelolaan pemasaran digital pada start - up. Penelitian merupakan studi kasus dalam upaya menunjukkan bagaimana sebenarnya dampak pemasaran digital pada para start-up. Penelitian ini merupakan penelitian kualitatif dengan pendekatan etnometodologi. Penelitian dilakukan dengan cara pengamatan langsung dan wawancara mendalam pada komunitas wirausaha baru yang menjadi vendor dalam start-up e-commerce di Fakultas Ekonomi Universitas Nusantara PGRI Kediri. Informan dipilih dengan kriteria 5 R. Pengamatan sendiri dilakukan pada saat terjadi transaksi penggunaan aplikasi digital marketing yang selanjutnya dilakukan wawancara terbuka untuk mengungkapkan dampak pengelolaan digital marketing. Hasil dari pengamatan dan wawancara mendalam pada penelitian ini menunjukkan bahwa dampak pengelolaan dari digital marketing pada start - up memang meningkatkan pendapatan start - up namun karena kurangnya kemampuan menyediakan konten dan merespon cepat atas konten - konten yang sudah disediakan menjadikan para wirausaha baru (start- up) belum mendapatkan hasil maksimal dari pengelolaan digital marketing tersebut.
\end{abstract}

Kata Kunci : Digital Marketing, Start - up, e-commerce 


\section{PENDAHULUAN}

Berdasarkan survei yang dilakukan oleh Asosiasi Penyelenggara Jasa Internet Indonesia pertumbuhan pengguna internet di Indonesia menempati urutan ke -6 dunia dengan 102 juta pengguna internet. Banyak faktor yang mempengaruhi perkembangan internet saat ini diantaranya infrastruktur teknologi informasi yang menyediakan akses internet yang menyeluruh dan cepat.

Fenomena geliat pengguna internet untuk perdagangan yang semakin bertambah mendorong munculnya bisnis - bisnis baru yang sekarang banyak dikatakan sebagai "start up business". Ries (2011) menjelaskan diantaranya start up merupakan sebuah usaha yang baru didirikan dan masih pada tahap pengembangan serta penelitian untuk mencari potensi pasar dan semua tergolong dalam bidang usaha teknologi dan informasi. Menurut kamus online cambridge.org, start-up adalah a small business that has just been started. Bisnis kecil yang baru dimulai. Sedangkan menurut business dictionary adalah tahap awal suatu perusahaan dimana pengusaha bergerak mulai dari tahap ide usaha, pembiayaan, meletakkan dasar struktur usaha kemudian memulai usaha. Sebagian orang mengartikan startup (start-up) adalah perusahaan yang baru dimulai dengan memanfaatkan teknologi, khususnya teknologi internet. Penetrasi dan efek internet tidak hanya memudahkan, memanjakan orang dalam berkomunikasi dan berinteraksi.Tetapi turut menyuburkan industri baru di bidang digital. Internet telah membuahkan bisnis-bisnis baru dengan pasarnya masing-masing (Hasanudin dkk, 2011:308). Beberapa karakteristik perusahaan startup tersebut diantaranya: (1) Usia perusahaan kurang dari 3 tahun. (2) Jumlah pegawai kurang dari 20 orang. (3) Pendapatan kurang dari \$100.000/tahun. (4) Masih dalam tahap berkembang. (5) Produk yang dibuat berupa aplikasi dalam bentuk digital. (6) Biasanya beroperasi melalui website.

Dari karakteristik tersebut mungkin nampak bahwa start-up lebih condong ke perusahaan yang bergerak di bidang teknologi dan web. Namun faktanya memang seperti itu, kini perkembangan perusahaan yang lazim dilabeli nama Start-up adalah perusahaan yang berkenaan dengan dunia tekno dan online. Perkembangan Start-up di Indonesia bisa dikatakan cukup pesat menggembirakan. Setiap tahun bahkan setiap bulan banyak founder-founder (pemilik) Start-up baru bermunculan. 
Menurut dailysocial.net, sekarang ini terdapat setidaknya lebih dari 1500 Start-up lokal yang ada di Indonesia. Potensi pengguna internet Indonesia yang semakin naik dari tahun ke tahun tentunya merupakan suatu lahan basah untuk mendirikan sebuah Startup. Menurut Rama Mamuaya, CEO dailysocial.net, Start-up di Indonesia digolongkan dalam tiga kelompok yaitu Start-up pencipta game, Start-up aplikasi edukasi serta Startup perdagangan seperti e-commerce dan informasi.

Berdasarkan data dari Startuprangking.com situs startup e-commerce di Indonesia yang populer diantaranya adalah Shopee,Tokopedia, Bukalapak, Blibli, Traveloka,Elevenia, Blanja.com, Zalora. Dari sekian banyak start-up e-commerce tersebut ternyata masih ada indikasi belum maksimalnya para vendor yang ada. Beberapa vendor yang masuk di start - up e-commerce tersebut masih belum mendapat hasil maksimal, sehingga para vendor yang notabene masih merupakan mahasiswa dan wirausaha baru terindikasi belum mampu maksimal dalam usahanya. Hal ini nampak pada survei awal yang dilakukan penulis pada para wirausaha baru yang juga merupakan mahasiswa dan alumni fakultas ekonomi Universitas Nusantara PGRI Kediri yang belum memaksimalkan usahanya.

Yang menarik adalah jika beberapa penelitian menyebutkan bahwa ada pengaruh sistem pemasaran digital marketing terhadap peningkatan volume penjualan seperti yang telah diteliti oleh Pradiani (2017),lalu mengapa masih ada vendor bisnis yang belum berhasil.

\section{Fokus Penelitian}

Yang menjadi fokus pada penelitian ini adalah bagaimana mengungkap dampak dari pengelolaan digital marketing yang dirasakan oleh para wirausaha baru yang merupakan mahasiswa dan alumni fakultas ekonomi UNPGRI Kediri serta faktor apa saja yang menyebabkan hasil pengelolaan digital marketing belum maksimal.

\section{Tujuan Penelitian}

Penelitian ini diharapkan mampu untuk mengungkap dampak dari pengelolaan digital marketing dan mengidentifikasi faktor penyebab hasil pengelolaan digital marketing belum maksimal sehingga nantinya juga dapat mengembangkan materi manajemen pemasaran yang efektif. 


\section{TINJAUAN PUSTAKA}

\section{Manajemen Pemasaran dalam Era Digital}

Pemasaran media online mulai populer sejalan dengan makin populernya penggunaan internet. Sebelum adanya pemasaran media online, kegiatan pemasaran membutuhkan biaya yang tidak sedikit. Akibatnya para perusahaan kecil atau yang baru bertumbuh tidak mampu melakukan aktivitas pemasaran secara optimal (Lasmadiarta, 2010:3). Strategi komunikasi pemasaran media online adalah melakukan aktivitas pemasaran dengan menggunakan semua fasilitas yang disediakan oleh internet dengan tujuan meningkatkan hasil penjualan dan menjalin komunikasi yang lebih baik kepada pelanggan. Pemasaran dengan internet pada dasarnya memiliki konsep yang sama, walaupun menggunakan sarana yang berbeda-beda. Oleh sebab itu, aktivitas pemasaran dilakukan tetap berpedoman pada market, produk, website, trafik dan kredibilitas (Lasmadiarta, 2010:9-19). Ada sejumlah alasan dari pengusaha mulai membidik pasar internet, diantaranya : (1) Para penonton tv mulai berpindah ke internet. (2) Pasar internet menggunakan iklan yang dapat diupdate setiap waktu dengan biaya minimal. (3) Pasar internet dapat menjangkau pembeli potensial dalam jumlah yang sangat besar dalam hitungan global. (4) Biaya iklan online lebih murah dan bisa menggunakan konvergensi teks, audio, grafik, dan animasi. (5) Internet sedang berkembang pesat secara interaktif dan mampu membidik kelompok tertentu dan atau perorangan. Saat ini target pasar yang dibidik yakni pengguna internet, sehingga perusahaan harus memfokuskan diri untuk melakukan promosi melalui internet (Salim, Joko, 2010)

Media online berfungsi sebagai promosi bisnis baik untuk produk barang maupun jasa. Hadirnya sosial media yang didukung oleh kekuatan internet saat ini berpotensi mendukung keberhasilan promosi suatu usaha atau produk dengan mudah, cepat dan murah, bahkan tanpa modal sama sekali. Apalagi dengan berbagai sarana beragam internet tools yang ada seperti website, blog, sosial media dan sifatnya yang global, real time dan praktis membuat kegiatan promosi usaha akan lebih maksimal. Beberapa media online sebagai media promosi handal untuk bisnis diantaranya sebagai berikut: (1) Facebook: Halaman utama facebook harus menarik konsumen dan upayakan calon konsumen memberikan like sebanyak-banyaknya. Selanjutnya, jangan lupa untuk mengenali target pelanggan dengan mencari orang-orang yang memiliki 
ketertarikan dengan halaman facebook serta fokuslah untuk membuat konten yang menarik.(2) Twitter: Beberapa cara untuk memaksimalkan promosi dan pemasaran produk melalui twitter adalah dengan memperbanyak jumlah follower, mengirimkan tweet secara teratur, mempromosikan situs secara teratur, menentukan waktu posting tweet, menyewa buzzer untuk meningkatkan promosi, atau dengan saling promo akun twitter bisnis online lainnya.(3) Instagram: Hashtag adalah salah satu kekuatan promosi yang luar biasa jika menggunakan instagram sebagai media bisnis. Selain itu, aktif berinteraksi dengan para pelanggan juga menjadi salah satu trik yang bisa membuat pelanggan menaruh perhatian. (4) Path: Daily beauty house merupakan salah satu bisnis yang melengkapi promosi mereka dengan menggunakan Path. Path merupakan bentuk private dari Facebook dan Twitter namun bukan berarti media sosial satu ini tidak bisa memberikan Anda kesempatan memperluas jaringan dan pasar.(5) Kaskus: sebagai market place yang banyak digunakan untuk berjualan dan dianggap sebagai media sosial paling ampuh untuk berbisnis terlebih dengan hadirnya forum jual beli. (6) Google+: sebagai media bisnis online dengan menyaring dan mengatur Gmail dengan Google+ Circles, membuat interaksi dengan Hangouts, mengedit dokumen bersama dengan rekan, dan juga merencanakan serta mengatur acara. (7) Market Place: pebisnis online dapat memiliki halaman toko sendiri dan melakukan aktivitas promo dan pemasaran produk. (8) Blog: pebisnis online yang menggunakan blog juga menggunakan teknik SEO guna semakin menarik lebih banyak pelanggan.(9) Email Marketing: memiliki kekuatan yang cukup besar untuk melakukan promosi secara online karena ini merupakan sumber besar untuk mengirimkan berita promosi hingga penawaran produk terbaru pada para pelanggan.(10) Youtube, mempromosikan bisnis dengan mengupload video melalui akun pribadi lalu pilih kategori yang tepat untuk jenis bisnis yang akan dipromosikan, judul video haruslah menarik dan mengandung banyak keywords yang banyak digunakan orang untuk memperbesar kemungkinan muncul pada laman pertama pada Youtube saat hasil pencarian video terkait keywords keluar.

Pemasaran digital adalah suatu usaha untuk mempromosikan sebuah merek dengan menggunakan media digital yang dapat menjangkau konsumen secara tepat waktu, pribadi, dan relevan.Tipe pemasaran digital mencakup banyak teknik dan praktik yang terkandung dalam kategori pemasaran internet. Dengan adanya 
ketergantungan pemasaran tanpa internet membuat bidang pemasaran digital menggabungkan elemen utama lainnya seperti ponsel, SMS (pesan teks dikirim melalui ponsel), menampilkan iklan spanduk, dan digital luar. Pemasaran digital turut menggabungkan faktor psikologis, humanis, antropologi, dan teknologi yang akan menjadi media baru dengan kapasitas besar, interaktif, dan multimedia. Hasil dari era baru berupa interaksi antara produsen, perantara pasar, dan konsumen.

Pemasaran melalui digital sedang diperluas untuk mendukung pelayanan perusahaan dan keterlibatan dari konsumen. Kunci sukses pemasaran digital: (1) Harus memperhatikan istilah pada AIDA (Awareness, Interest, Desire, dan Action). (2) Pasar adalah tempat komunikasi dua arah. Untuk memperoleh komunikasi tersebut merek harus melakukan positioning terlebih dahulu, dapat melalui berbagai media (Forum, blog, dan lain-lain) dan yang paling efektif ialah melalui jejaring sosial. Aturan dalam pemasaran digital : (1) Menargetkan satu segmen dan menciptakan komunitas virtual. (2) Memperluas peran merek dalam portofolio secara global. (3) Gunakan harga yang kreatif. (4) Mengutamakan desain bagi konsumen.(5) Gunakan eksperimentasi yang bersifat adaptif. (6) Menemukan kembali riset pemasaran dan pemodelan sebagai penciptaan pengetahuan.

Perdagangan elektronik: electronic commerce atau e-commerce adalah penyebaran, pembelian, penjualan, pemasaran barang dan jasa melalui sistem elektronik seperti internet atau televisi, www, atau jaringan komputer lainnya. E-commerce dapat melibatkan transfer dana elektronik, pertukaran data elektronik, sistem manajemen inventori otomatis, dan sistem pengumpulan data otomatis. Industri teknologi informasi melihat kegiatan e-commerce ini sebagai aplikasi dan penerapan dari ebisnis (e-business) yang berkaitan dengan transaksi komersial, seperti: transfer dana secara elektronik, SCM (supply chain management), pemasaran elektronik (emarketing), atau pemasaran online (online marketing), pemrosesan transaksi online (online transaction processing), pertukaran data elektronik (electronic data interchange /EDI), dll. E-commerce merupakan bagian dari e-business, di mana cakupan e-business lebih luas, tidak hanya sekadar perniagaan tetapi mencakup juga pengkolaborasian mitra bisnis, pelayanan nasabah, lowongan pekerjaan dll. E-commerce adalah pembelian, penjualan dan pemasaran barang dan jasa melalui sistem elektronik (Wong, Jony, 2010) E-commerce yang biasa digunakan adalah tokopedia, bukalapak, sophie, tokobagus, dan 
lain-lain.Selain teknologi jaringan www, e-commerce juga memerlukan teknologi basisdata atau pangkalan data (databases), surat elektronik (e-mail), dan bentuk teknologi non komputer yang lain seperti halnya sistem pengiriman barang, dan alat pembayaran untuk e-dagang. Beberapa aplikasi umum yang berhubungan dengan ecommerce adalah: (1) E-mail dan Messaging. (2) Content Management Systems. (3) Dokumen, spread sheet, database. (4) Akunting dan sistem keuangan. (5) Informasi pengiriman dan pemesanan.(6) Pelaporan informasi dari klien dan enterprise. (7) Sistem pembayaran domestik dan internasional. (8) News group. (9) Online Shopping. (10) Conferencing. (11) Online Banking/internet Banking (12) Product Digital/Non-digital. (13) Online SEO.

\section{Strategi Meyakinkan Calon Pelanggan Secara Online}

Menurut Wandanaya (Wandayana, Anita, 2012)mempunyai produk andalan saja belum cukup untuk mengundang calon pelanggan membeli produk, dengan banyaknya persaingan sekarang ini, sering kali penjual harus melancarkan strategi jitu dalam mempengaruhi pelanggan. Berikut adalah beberapa cara yang dapat dilakukan: (1) Menguasai product knowledge. (2) memastikan target konsumen. (3) Menggunakan gaya bahasa yang memikat. (4) Menulis deskripsi lengkap mengenai keunggulan dan manfaat produk perusahaan. (5) Menambahkan berbagai gambar atau video yang memikat visualisasi konsumen. (6) Promosi yang spektakuler. (7) Memberikan layanan penjualan secara profesional (8) Cepat dalam merespon konsumen.

\section{METODE PENELITIAN}

\section{Jenis Penelitian}

Penelitian ini merupakan penelitian kualitatif dengan pendekatan etnometodologi. Secara normatif, etnometodologi dapat didefinisikan sebagai studi tentang “......everyday activities asa members method for makng those same activities visibly - rational - and reportable - for - all- practical- purpose i.e. "accountable" as organisations of commonplace everyday activities". Jadi , fokus studi etnometodologi adalah aktivitas yang bersifat rutin dan merujuk pada aktivitas keseharian kelompok bukan individu (Kamayanti, Ari, 2015).

\section{Kehadiran Peneliti}


Pada penelitian ini peneliti yang bertindak sebagai seorang etnometodologis langsung menjadi participant observer agar dapat langsung memperoleh bentuk aktivitas dan merelasikannyalangsung dengan indeksikalitas dan refleksivitas.

\section{Lokasi Dan Subyek Penelitian}

Dalam penelitian ini lokasi yang diteliti berada di Fakultas Ekonomi Universitas Nusantara PGRI Kediri, yang mana FE memiliki banyak mahasiswa dan alumni yang menjadi wirausaha. Subyek dalam penelitian ini adalah mahasiswa dan alumni fakultas ekonomi Universitas Nusantara PGRI Kediri.

\section{Pemilihan Informan}

Informan dalam penelitian kualitatif merupakan aspek yang paling penting. Oleh karenanya, penting sekali untuk memilih informan sesuai dengan kriteria berikut ini:

1. Relevance

Yang dikatakan relevance dalam penelitian ini berarti informan terkait dengan masalah yang diteliti.

2. Recomendation

Disini informan didapat atas dasar rekomendasi dari orang - orang yang terpercaya.

3. Rapport

Untuk menggali informasi lebih dalam, maka sebagai peneliti harus memastikan apakah informan bisa dekat dengan peneliti atau tidak.

4. Readiness

Informan dalam penelitian kualitatif harus benar - benar dipastikan siap diwawancarai.

5. Reassurance

Informan yang diambil benar - benar bicara sesuai dengan kebenaran.

\section{Sumber Data}

Sumber data merupakan salah satu bagian penting dalam penelitian. Pentingnya data untuk memenuhi dan membantu serangkaian permasalahan yang terkait dengan 
fokus penelitian. Sumber data yang digunakan dalam penelitian ini adalah data primer dan sekunder. Yang mana data didapat dari informan langsung dan untuk melengkapi data dari informan, peneliti juga mencari informasi berupa dokumen - dokumen grafis, foto - foto, rekaman, video.

\section{Prosedur Pengumpulan Data}

Proses pengumpulan data pada penelitian ini menggunakan beberapa teknik diantaranya :

1. Observasi

Dalam observasi ini peneliti melakukan pengamatan dan yang sistematis terhadap gejala - gejala yang diteliti. Peneliti melakukan observasi awal dengan cara berkumpul dengan komunitas startup.

2. Wawancara mendalam

Wawancara yang dilakukan peneliti dalam penelitian ini merupakan alat rechecking atau pembuktian terhadap informasi atau keterangan yang diperoleh sebelumnya. Wawancara ini dilakukan dengan tujuan untuk memperoleh keterangan dengan tanya - jawab sambil bertatap muka antara pewawancara dengan informan dengan atau tanpa pedoman wawancara, yang mana dalam hal ini pewawancara dan informan dapat terlibat dalam kehidupan sosial yang relatif lama.

3. Dokumentasi

Dalam kegiatan penelitian ini, peneliti mengambil data berupa catatan, gambar, buku agenda, dan sebagainya terkait manajemen pemasaran digital pada startup.

\section{Tahapan Analisis Dan Teknik Penarikan Kesimpulan}

Dalam mempelajari aktivitas keseharian yang disepakati bersama anggota kelompok, Grafinkel menetapkan tiga tahap analisis yaitu :

1. Tahap pertama : Analisis Indeksikalitas

Tahap ini merupakan tahap untuk mencari dan memahami tema yang disetujui oleh kelompok pelaku usaha kecil. Pada tahap ini peneliti akan membuat indeks - indeks tema melalui ungkapan maupun bahasa tubuh pelaku startup . 
2. Tahap kedua : Analisis Refleksivitas

Setelah peneliti melakukan pengamatan dan menemukan ekspresi indeksikalitas, maka penulis akan menelaah refleksivitas dari ekspresi tersebut. Hal ini akan ditampilkan pada kertas kerja seperti berikut :

Tabel 3.1 Kertas Kerja Pencarian Kesepakatan Umum (Common Understanding)

\begin{tabular}{|l|l|lr|}
\hline Informan & Percakapan (Interaksi) & $\begin{array}{l}\text { Pemahaman } \\
\text { (Implisit) } \\
\text { interaksi }\end{array}$ & $\begin{array}{r}\text { Bersama } \\
\text { tentang }\end{array}$ \\
\hline $\begin{array}{l}\text { 1.Informan 1 } \\
\text { 2. Informan 2 } \\
\text { 3.dst }\end{array}$ & $\begin{array}{l}1 \ldots \ldots \ldots \ldots \ldots \\
1 \ldots \ldots \ldots \ldots . .\end{array}$ \\
\hline
\end{tabular}

3. Tahap ketiga : Analisis Aksi Kontekstual

Tahap ketiga studi etnometodologi dalam penelitian ini adalah mengungkapkan aktivitas keseharian bersifat praktis yang dapat dikenali (recognizable) da dapat dilaporkan (visible). Mahkota penelitian etnometodologi adalah suatu penjelasan tentang keteraturan dan keterkaitan antara ekspresi indeksikalitas, rasionalisasi atas ekspresi indeksikalitas dan akan berakhir pada sebuah aksi indeksikalitas. Hal ini akan terlihat seperti gambar dibawah ini :

Gambar 3.1 Order antara ekspresi dan aksi Indekskalitas

ekspresi indeksikalitas organisasi rasionalisasi (studi

refleksivitas) aksi indekskalitas

organisasi

4. Tahap keempat : Penyajian Common Sense Knowlwdge of Social Structures

Penelitian ini bermuara pada pemahaman pola struktur sosial. Dari etnometodologi ini kami peneliti akan mendapatkan gambaran tentang indeks yang dilakukan dalam 
keseharian dan kesepakatan komunitas. Dari hasil gambaran ini, pemahaman relasi indeks dan refleksivitas akan mengungkap aksi indeksikalitas yang terbentuk. Akhirnya pemahaman ini akan mengarah pada budaya umum. Jadi jelas apa saja dampak dari pengelolaan digital marketing serta faktor apa saja menyebabkan hasil pengelolaan digital marketing belum maksimal.

HASIL DAN PEMBAHASAN

\begin{tabular}{|l|l|l|}
\hline Percakapan(Interaksi) & $\begin{array}{l}\text { Pemahaman Bersama } \\
\text { tentang Interaksi } \\
\text { Informan 1 }\end{array}$ & $\begin{array}{l}\text { Pemahaman } \\
\text { Bersama tentang } \\
\text { Interaksi } \\
\text { Informan 2 }\end{array}$ \\
\hline $\begin{array}{l}\text { Kurang Fokusnya Pengelolaan } \\
\text { Bisnis produk berbasis data }\end{array}$ & Ya & Ya \\
\hline $\begin{array}{l}\text { Kurang pengalaman dalam } \\
\text { mengelola konten yang disediakan } \\
\text { dan kurang cepat dalam merespon }\end{array}$ & Ya & Ya \\
\hline
\end{tabular}

Kurang Fokusnya Pengelolaan Bisnis produk berbasis data

Pemasaran digital yang berfokus pada pemanfaatan internet menuntut para pelaku terus dapat menyediakan data dalam bentuk digital. Data tersebut memiliki isi yang bermutu, sesuai dengan karakter pelaku startup dan barang yang dijual. Data digital terkait produk yang dipromosikan dalam pemasaran digital tetap harus dikemas dengan bahasa yang memikat, kata-kata yang terangkai dapat menimbulkan daya tarik,diskripsi pemahaman tentang produk secara detail tersampaikan, pembuatan visual produk dari sisi bentuk, engle pengambilan, pencahayaan merupakan sebuah kebutuhan dasar yang harus dipenuhi dari sebuah data digital sebelum data tersebut ditampilkan dalam berbagai media online.

Hal ini disetujui oleh "Mas R" selaku mahasiswa yang tergabung dalam komunitas wirausaha baru berbasis digital. Dalam perbincangan santai di kampus, Mas $\mathrm{R}$ menyatakan "gelang adventure kaya gini, lakunya dijual online bu(sambil menghadap peneliti)soalnya pangsa pasarnya komunitas adventure gitu. Tapi ya butuh keakuratan data, makanya saya masih tangani sendiri pembuatan produknya dan 
penjualannya. Kalo moto pun tidak bisa asal- asalan harus bagus, nulis caption juga harus detil. Karena semua itu penting” bahwa produknya yang berupa gelang untuk adventure ini kalau dijual langsung seperti pada saat pameran hasilnya biasa saja, lebih banyak penjualan via online karena pangsa pasarnya komunitas -komunitas adventure. Namun, mas Raka menambahkan bahwa keakuratan data untuk memasarkan produk sangatlah penting. Kualitas Foto, informasi spesifikasi produk sangat penting. Kalau masih sambil kuliah memang agak kurang bisa fokus sih bu (lanjut mas R) jadi kurang maksimal ngelola bisnis ini.

Kemudian Mas W juga menambahkan" ya bener memang harus gitu bu (membenarkan statement sebelumnya) soalnya minyak penumbuh bulu saya ini sudah pernah dipesan orang luar juga, jadi saya harus pinter" yang ini berarti bahwa produknya yang berupa penumbuh rambut itu juga demikian. Jadi memang harus benar - benar tahu spesifikasi produknya dan tahu caranya merangkai kata serta membuat konten yang menarik. Namun saya sendiri masih kurang fokus karena masih bagi - bagi waktu. Masih sambil mengerjakan tugas kuliah yang banyak bu.

Seperti diungkapkan Purbo dan Wahyudi (Purbo, O.W. dan Wahyudi, A.A., 2001) yang menyatakan bahwa dalam konsep e-commerce diwebsite alur kerjanya adalah sebagai berikut :

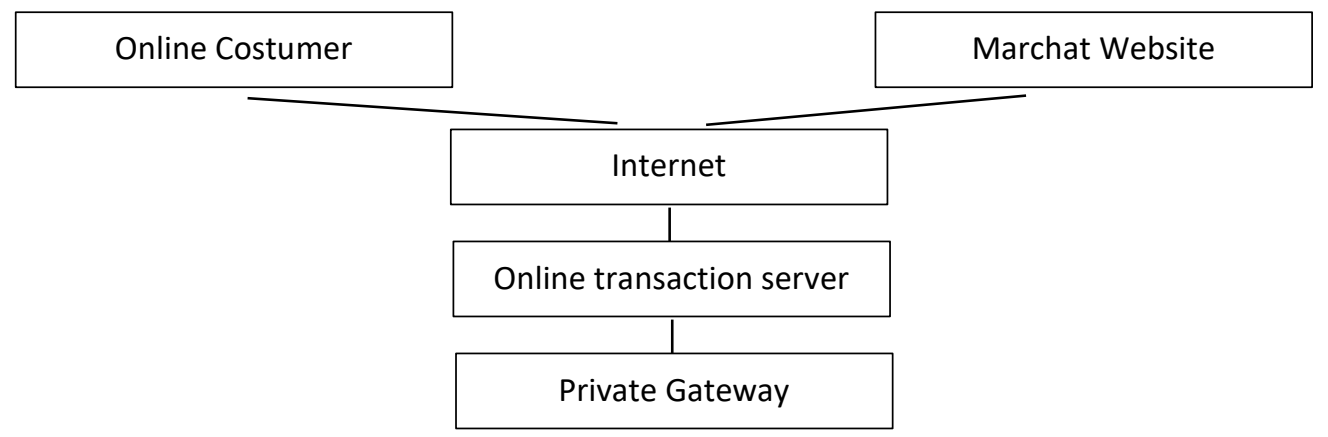

Gambar 1 . Peta E- Commerce (Purbo, O.W. dan Wahyudi, A.A., 2001)

Dari gambar diatas jelas terlihat bahwa konsumen online berhubungan langsung dengan website dan melakukan transaksi online dengan private gateway, sehingga penting bagi penjual untuk selalu memperbarui datanya. Berdasarkan pengamatan peneliti juga didapatkan bahwa ada kebiasaan dari para startup di Komunitas ini yang belum fokus dalam pengelolaan bisnis berbasis data ini. Hal ini nampak dari belum 
adanya keunggulan operasional itu sendiri. Para startup sendiri menyadari bahwa dampak dari pemasaran digital itu bagus untuk meningkatkan omset tapi disisi lain para startup tersebut juga belum bisa mengoperasionalkan secara maksimal sistemnya.

Seperti halnya penelitian Treacy dan Wiersema pada 80 perusahaan pemimpin pasar berhasil mengidentifikasi tiga kelompok disiplin yang dapat dijadikan tumpuan untuk memenangkan persaingan yaitu : Keunggulan operasional, Kepemimpinan Produk dan Keakraban dengan pelanggan. Hal ini nampaknya perlu sekali diadopsi oleh para startup agar semakin mampu bersaing di pasar. Penelitian lain menyebutkan bahwa " Digital environments surrounding startups provide relevant data and quick feedback responses for them to any variations in content and applications of their digital marketing. This allows them to develop relevant business activities following some kind of experimental trial and error method. In this study a case is described where a German startup followed an experimental method to optimize their application of online videos in digital marketing. Expending “classical” lean startup approaches this paper proposes that experimental methods should be further developed and validated as organizational process models for startups and could be applied fora " (Beier, 2016), yang hal ini berarti bahwa para start up dimungkinkan untuk mengembangkan aktivitas bisnis yang relevan mengikuti pengalaman mencoba dan gagal bukan menyerah dengan alasan kurangnya kemampuan untuk fokus pada pengelolaan bisnis berbasis data.

\section{Startup belum berpengalaman dengan konten yang di buatnya dan kurang cepat merespon}

Para startup mengaku bahwa kurang pengalaman dalam membuat konten yang menarik dan tidak selalu standby smartphonenya sehingga kurang cepat dalam merespon konsumen. Terlebih lagi startup tersebut juga masih kuliah sehingga menyesuaikan waktunyapun kesulitan. Ms. R menyatakan bahwa sekarang saya itu bingung bagi waktu bu soalnya kalau tugas kuliah banyak, saya g bisa melayani konsumen secara maksimal. Yang beli banyak tapi saya ga bisa melayani dan memenuhi permintaan.

Sedangkan untuk startup yang sudah lulus kuliah pun, masih sering sibuk untuk mencari pekerjaan lain dengan gaji pasti sehingga usaha yang dirintisnya masih dianggap sebagai sampingan saja. Hal diatas dikuatkan oleh pendapat Mr. W yang 
menyatakan bahwa kadang konten yang dibuatnya hanya seadanya saja. Saya masih pingin cari kerja kantoran. Soalnya kalau dagang kan masih resiko kalau barangnya tidak laku.

Mindset seperti diatas nampaknya menjadi hal yang menghambat mereka sendiri dalam bisnis ini. Karena untuk para start - up butuh waktu yang lebih banyak untuk percobaan, butuh untuk terus mencoba meskipun gagal, mengingat jamannya sudah bukan pemasaran klasik namun pemasaran digital

\section{SIMPULAN DAN REKOMENDASI}

Dari temuan diatas dapat disimpulkan bahwa dampak pengelolaan dari digital marketing pada start - up memang meningkatkan pendapatan start - up namun karena kurangnya fokus para start up atas pengelolaan bisnis berbasi data serta kemampuan menyediakan konten dan merespon cepat atas konten - konten yang sudah disediakan menjadikan para wirausaha baru (start-up) belum mendapatkan hasil maksimal dari pengelolaan digital marketing tersebut. Untuk dapat menerima hasil maksimal dari pengelolaan pemasaran digital, diperlukan konsentrasi, pengalaman untuk berani mencoba dan gagal, dibutuhkan kemampuan membuat konten yang bagus dan juga kecepatan dalam merespon konsumen. Dari penelitian ini diharapkan dapat digunakan sebagai kajian oleh para pihak terkait untuk membantu dan melatih para wirausaha baru ini.

\section{DAFTAR PUSTAKA}

Beier, Michael (2016): Startups' Experimental Development of Digital Marketing Activities. A Case of Online-Videos. Social Science Research Network (SSRN)Electronic Journal, Paper: 2868449.

Hasanudin, dkk. 2011. Anxieties Desires: 90 Insights for Marketing to Youth, Women, Netizen in Indonesia. Jakarta:PT Gramedia Pustaka Utama.

Kamayanti A. 2015. Metodologi Penelitian Akuntansi. Jakarta: Yayasan Rumah Peneleh.

Kotler, Philip. 2005. Manajamen Pemasaran. Jakarta: PT. Indeks Kelompok Gramedia. 
Kotler, Philip dan Kevin Lane Keller. 2009. Manajemen Pemasaran. Jakarta: Erlangga.

Lasmadiarta, Made. 2010.Extreme Facebook Marketing for Giant Profits. Jakarta:

Purbo, O.W., dan Wahyudi A.A (2001). Mengenal E-Commerce”.Jakarta:PT. Elex Media Komputindo.

Salim, Joko. 2010. Online Entrepreneur. Jakarta:PT Elex Media Komputindo

Soemanagara, Dermawan. 2006. Strategic Marketing Communications, Konsep Strategis, dan Terapan. Bandung: CV Alfabeta.

Wandanaya, Anita. 2012. "Pengaruh Pemasaran Online terhadap Keputusan Pembelian Produk”. Journal CCIT (Creative Communication And Innovative Technology) Vol. 5 No. 2

Wong, Jony. 2010. Internet Marketing untuk Awal. Jakarta: Elex Media Komputindo 